\title{
ERIC-PCR GENOTYPIC CHARACTERIZATION OF HAEMOPHILUS PARASUIS ISOLATED FROM BRAZILIAN SWINE
}

\author{
Luisa Zanolli Moreno ${ }^{1}$, Karina Salvagni Castilla ${ }^{1}$, Débora Dirani Sena de Gobbi ${ }^{1}$, Tania Alen Coutinho ${ }^{1}$, Thais Sebastiana \\ Porfida Ferreira ${ }^{1}$, Andrea Micke Moreno ${ }^{1,2 *}$
}

${ }^{1}$ Laboratório de Sanidade Suína e Virologia, Faculdade de Medicina Veterinária e Zootecnia, Universidade de São Paulo, Sao
Paulo, SP, Brasil; ${ }^{2}$ Laboratório de Sanidade Suína e Virologia, Faculdade de Medicina Veterinária e Zootecnia, Universidade de São Paulo, Sao Paulo, SP, Brasil.

Submitted: August 09, 2010; Returned to authors for corrections: February 11, 2011; Approved: June 06, 2011.

\begin{abstract}
Haemophilus parasuis infection, known as Glässer's disease, is characterized by fibrinous polyserositis, arthritis and meningitis in piglets. Although traditional diagnosis is based on herd history, clinical signs, bacterial isolation and serotyping, the molecular-based methods are alternatives for species-specific tests and epidemiologic study. The aim of this study was to characterize $H$. parasuis strains isolated from different states of Brazil by serotyping, PCR and ERIC-PCR. Serotyping revealed serovar 4 as the most prevalent $(24$ $\%)$, followed by serovars $14(14 \%), 5(12 \%), 13(8 \%)$ and $2(2 \%)$, whereas $40 \%$ of the strains were considered as non-typeable. From 50 strains tested $43(86 \%)$ were positive to Group 1 vtaA gene that have been related to virulent strains of H.parasuis. ERIC-PCR was able to type isolates tested among 23 different patterns, including non-typeable strains. ERIC-PCR patterns were very heterogeneous and presented high similarity between strains of the same animal or farm origin. The results indicated ERIC-PCR as a valuable tool for typing $H$. parasuis isolates collected in Brazil.
\end{abstract}

Key words: Haemophilus parasuis; Glässer disease; Genotyping; ERIC-PCR.

\section{INTRODUCTION}

Haemophilus parasuis is the etiological agent of Glässer's disease which is characterized by fibrinous polyserositis, arthritis and meningitis that can affect pigs from 2 weeks to 4 months old (11). It is a non-motile, pleomorphic, Gramnegative bacillus of the Pasturellacea family, nicotinamide adenine dinucleotide (NAD) dependent bacterium (1) which colonizes the upper respiratory tract of pigs before weaning (20). Therefore, samples of pleura, peritoneum, joints and meninges are preferable for clinical diagnosis (17), since $H$. parasuis can be isolated from the upper respiratory tract of healthy pigs.

The strains of $H$. parasuis were classified by serotyping in 15 serovars and demonstrated differences in their virulence, classifying strains from highly virulent to non-virulent (7). 
However, no clear correlation between serovar and virulence has been defined, since strains belonging to the same serotype can exhibit different degrees of virulence. Nevertheless, serotyping has been useful for vaccine production, but it is not discriminative enough for epidemiologic studies, since 15 to $41 \%$ of the isolates are non-typeable through the Kielstein and Rapp-Gabrielson (KRG) serotyping method $(15,22)$. For this reason, molecular methods have been developed to improve diagnosis and epidemiological characterization of $H$. parasuis.

Santos et al. (23) first described high incidence of serovars 1, 4, 5 and 12, which were considered from moderate to high virulence. Since then, few studies have been developed with $H$. parasuis in Brazil, but the epidemiology of the infection is still unknown. Therefore, the aim of this study was to characterize Haemophilus parasuis isolates collected in different States in Brazil, by serotyping, PCR and ERIC-PCR.

\section{MATERIAL AND METHODS}

\section{Bacterial strains}

Fifty isolates were evaluated in this study. The strains were isolated from lungs of 23 pigs with clinical signs of arthritis, meningitis, peritonitis and/or pericarditis, in 21 herds from four different States (Mato Grosso, Minas Gerais, Paraná and São Paulo) in Brazil. All isolates were maintained at $-80^{\circ} \mathrm{C}$ until analysis.

\section{Serotyping}

The strains were grown on Brain Heart Infusion (BHI Difco-BBL, Detroit, MI /USA) supplemented with NAD (0.01 $\%$ ) and fetal calf serum ( $5 \%$ ) from 24 to $48 \mathrm{~h}$ at $37^{\circ} \mathrm{C}$, under microaerophilic conditions (5\% of $\mathrm{CO}_{2}$ ). Serotyping was carried out on 50 isolates by immunodiffusion test using autoclaved antigens (7) at the Microvet Laboratory of Veterinary Microbiology, Minas Gerais, Brazil.

\section{DNA preparation and PCR}

Purified DNA was recovered with Boom et al. (3) protocol of DNA extraction and stored at $-20^{\circ} \mathrm{C}$. The 50 strains were identified by PCR based on species-specific amplification of the 16S rRNA gene as described by Oliveira et al. (12) and by amplification of Groups 1 and $3 v t a A$ genes described by Olvera et al. (19). The PCR directed to $16 \mathrm{~S}$ rRNA gene was performed in a $20 \mu 1$ reaction mixture containing $1 \mu \mathrm{l}$ of extracted DNA, $0.3 \mathrm{mM}$ of each primer, $50 \mathrm{mM} \mathrm{KCl}, 10 \mathrm{mM}$ Tris- $\mathrm{HCl}, 1.5 \mathrm{mM} \mathrm{MgCl} 2,5 \mu \mathrm{l}$ of PCR buffer, $0.24 \mathrm{mM}$ of each deoxynucleoside triphosphate, and $0.5 \mathrm{U}$ of Taq DNA polymerase (LGC Biotecnologia, São Paulo, Brazil). The PCR was carried out for 30 cycles consisting of denaturation for 30 seconds at $94{ }^{\circ} \mathrm{C}$, annealing for 30 seconds at $59{ }^{\circ} \mathrm{C}$, and extension for 2 minutes at $72 \mathrm{C}$. The PCR to detect Groups 1 and $3 v t a \mathrm{~A}$ genes was performed in a $25 \mu 1$ reaction mixture containing $2.5 \mu \mathrm{l}$ of extracted DNA, $800 \mathrm{mM}$ of primer YADAF1 e PADHR1, $400 \mathrm{mM}$ dos primers YADAF3 e PADHR3, $50 \mathrm{mM} \mathrm{KCl,} 10 \mathrm{mM}$ Tris-HCl, $2 \mathrm{mM} \mathrm{MgCl} 2,5 \mu \mathrm{l}$ of PCR buffer, $0.4 \mathrm{mM}$ of each deoxynucleoside triphosphate, and $1 \mathrm{U}$ of Taq DNA polymerase (LGC Biotecnologia, São Paulo, Brazil). Cycling conditions were $5 \mathrm{~min}$ at $94^{\circ} \mathrm{C}$, followed by 25 cycles of $45 \mathrm{~s}$ at $94{ }^{\circ} \mathrm{C}, 45 \mathrm{~s}$ at $64{ }^{\circ} \mathrm{C}$ and $1 \mathrm{~min}$ at $72{ }^{\circ} \mathrm{C}$, then a final incubation at $72^{\circ} \mathrm{C}$ for $7 \mathrm{~min}$.

The amplified products were separated by electrophoresis in $1.5 \%$ or $2.5 \%$ agarose gel stained with ethidium bromide. The 100bp DNA ladder (LGC Biotecnologia, São Paulo, Brazil) was used for molecular weight determinations.

\section{Enterobacterial Repetitive Intergenic Consensus Sequences (ERIC-PCR)}

ERIC-PCR was performed as described previously by Versalovic et al. (25), using $5 \mu \mathrm{l}$ from extracted DNA, $1.5 \mathrm{mM}$ of $\mathrm{MgCl}_{2}, 10$ pmoles from primers ERIC1 (ATGTAA GCTCCTGGGGATTCAC) and ERIC2 (AAGTAAGTGACTG GGGTGAGCG), $1.0 \mathrm{U}$ of Taq DNA polymerase (LGC Biotecnologia, São Paulo, Brazil), 1 X of PCR buffer and water to complete the total volume of $50 \mu \mathrm{l}$. PCR reaction was carried out with 35 cycles consisting of denaturation for $4 \mathrm{~min}$ at $94^{\circ} \mathrm{C}$, annealing for $60 \mathrm{sec}$ at $50^{\circ} \mathrm{C}$, and extension of $2.5 \mathrm{~min}$ 
at $72^{\circ} \mathrm{C}$, increased with a final extension of $20 \mathrm{~min}$ at $72^{\circ} \mathrm{C}$ as described by Raffie et al. (21). Amplification products were detected through electrophoresis at $35 \mathrm{~V}$ for $20 \mathrm{~h}$ in $2 \%$ Agarose 1000 (Invitrogen Corporation, Carlsbad, CA/USA) gel stained with ethidium bromide.

\section{Data analysis}

ERIC-PCR fingerprints analysis and similarity matrix calculations were carried out using Simple Matching coefficient and cluster analysis of fingerprints was performed using the unweighted-pair group method (UPGMA) by means of the NTSYS software to generate dendrogram. A 90\% cut-off was used to analyze the genotypes generated by ERIC-PCR technique according to Oliveira et al. (13). Discriminatory index was calculated as described by Hunter and Gaston (6).

\section{RESULTS}

\section{Serotyping and PCR}

Serovar 4 was the most prevalent (24\%), followed by serovars $14(14 \%), 5(12 \%), 13(8 \%)$ and $2(2 \%)$, whereas $40 \%$ of the strains were considered non-typeable. Strains from different serovars were identified on specimens from the same animal and same farm, as showed by Table 1. All tested strains were positive to species-specific amplification of the $16 \mathrm{~S}$ rRNA gene as described by Oliveira et al. (12) and to Group 3 $v t a \mathrm{~A}$ gene described by Olvera et al. (19). From 50 strains tested $43(86 \%)$ were positive to Group 1 vtaA gene.

Table 1. Serovar distribution of $H$. parasuis isolates according with animal, farm of origin, State and year of isolation.

\begin{tabular}{|c|c|c|c|c|}
\hline Animal & Farm & Serovar & State & Year \\
\hline A1 & F1 & 5,5 & $\mathrm{SP}^{2}$ & 2004 \\
\hline $\mathrm{A} 2$ & $\mathrm{~F} 2$ & $4, \mathrm{NT}^{1}, 4$ & SP & 2004 \\
\hline A3 & F3 & $4,5,4$ & SP & 2005 \\
\hline A4 & F4 & 4,4 & SP & 2004 \\
\hline A5 & F4 & 13 & SP & 2005 \\
\hline A6 & F5 & 5,5 & SP & 2005 \\
\hline A7 & F6 & NT, NT, 4 & SP & 2005 \\
\hline A8 & F7 & 14,UT,14 & SP & 2005 \\
\hline A9 & F8 & $\mathrm{NT}, \mathrm{NT}, \mathrm{NT}$ & SP & 2005 \\
\hline A10 & F9 & NT, 2 & SP & 2005 \\
\hline A11 & F10 & $4,4, \mathrm{NT}$ & SP & 2005 \\
\hline A12 & F11 & NT, NT & $\mathrm{PR}^{3}$ & 2005 \\
\hline A13 & F12 & 5 & PR & 2006 \\
\hline A14 & F13 & $4, \mathrm{NT}, \mathrm{NT}, \mathrm{NT}$ & SP & 2006 \\
\hline A 15 & F14 & NT & $\mathrm{MT}^{4}$ & 2006 \\
\hline A16 & F15 & 14 & SP & 2006 \\
\hline A17 & F16 & $4, \mathrm{NT}, \mathrm{NT}$ & SP & 2006 \\
\hline A18 & F17 & NT & MT & 2007 \\
\hline A19 & F18 & 14,14 & PR & 2007 \\
\hline A20 & F18 & 14,14 & PR & 2007 \\
\hline A21 & F19 & NT & MT & 2007 \\
\hline A 22 & F20 & 4 & $\mathrm{MG}^{5}$ & 2007 \\
\hline A23 & F21 & $\mathrm{NT}, 13,13,13$ & MG & 2007 \\
\hline
\end{tabular}

${ }^{1}$ non-typeable strains, ${ }^{2}$ São Paulo, ${ }^{3}$ Paraná, ${ }^{4}$ Mato Grosso and ${ }^{5}$ Minas Gerais 


\section{ERIC-PCR analysis}

All 50 strains were examined and identified with the ERIC-PCR technique. Analysis of ERIC profiles utilizing a 90\% cut-off revealed 23 distinct genotypes. ERIC patterns for $H$. parasuis isolates were highly heterogeneous, with DNA fragments ranging from 150 to $1300 \mathrm{bp}$ in size. The ERIC-PCR dendrogram (Figure 1) distributed the $50 \mathrm{H}$. parasuis strains in two main groups with more than $70 \%$ of similarity. Group I comprised composed by 36 of tested strains from profiles 1 to 13. Inside these subtypes, strains from same animal and farm origin were clustered in an identical genotype, as well as strains from different animals, farms, state and even from different serotypes, were grouped in the same genetic profile. Group II comprised profiles 14 to 23 with $H$. parasuis isolates, ranging from $80 \%$ to $100 \%$ of similarity, 9 of which were nontypeable by serotyping.

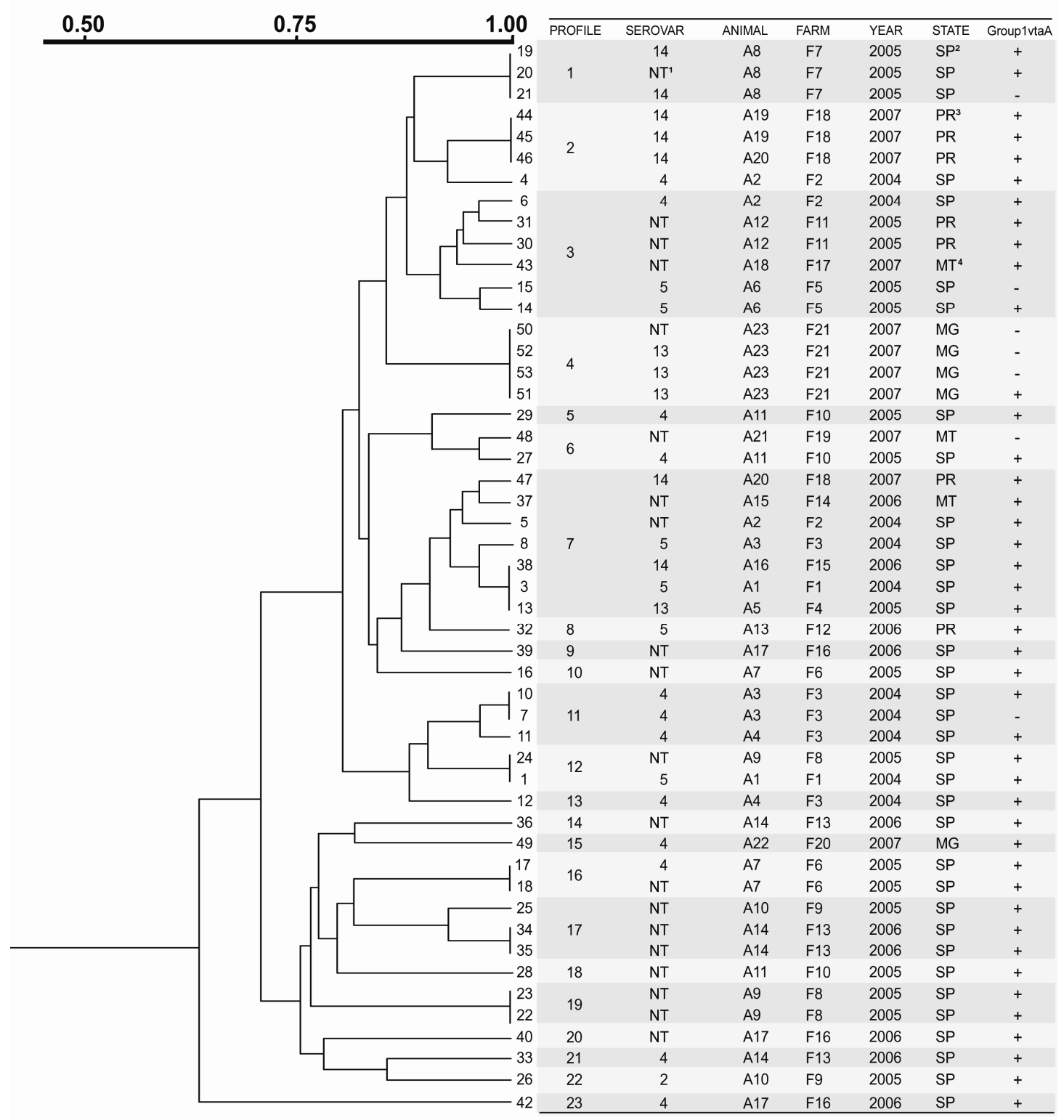

Figure 1. ERIC-PCR dendrogram. Percentages of similarity between profiles were calculated by use of Dice's coefficient. The dendrogram was constructed by use of UPGMA (unweighted pair group method using arithmetic average). 


\section{Discriminatory power}

The discriminatory index obtained for serotyping and ERIC-PCR were 0.75 and 0.95 , respectively.

\section{DISCUSSION}

In this study, the application of the molecular typing method, ERIC-PCR, PCR and traditional serotyping method were used to characterize Haemophilus parasuis strains isolated from swine of different states in Brazil. Serotyping was able to characterize $60 \%$ of the isolates among five different serovars, including highly pathogenic strains (serovars 5, 13 and 14). The serovar 4 was the most prevalent (24\%) among $H$. parasuis strains; however, more than $40 \%$ of the isolates tested were non-typeable by serotyping, which is compliant with Oliveira and Pijoan (15) findings that reported non-typable isolates as one of the most prevalent in United States herds. Macedo et al. (8) also reported high prevalence of serovar $4(15.9 \%)$ and non-typeable (60.3\%) strains on Brazilian territory. The occurrence of non-typeable strains is one limitation of serotyping as an epidemiological tool. For this reason, other techniques such as molecular methods are being developed to improve the study of the $H$. parasuis epidemiology.

Olvera et al (19) developed a PCR to characterize trimeric autotransporters genes ( $v t a A)$ associated to virulence, they describe that group $3 \mathrm{vtaA}$ gene seems to be conserved among invasive and non-invasive strains and may be used to species identification, while group 1 vtaA gene showed better correlation with virulent strains. In the present study, all strains were isolated from lungs of swine with clinical signs of Glasser's disease and the frequency of $v \operatorname{taA} 1$ gene was high as could be expected (86\%). Olvera et al, (19), also describe the occurrence of $v t a A 1$ negative isolates from lungs as observed in seven strains examined here. In some cases were selected more than one isolate from the same animal, and was observed that six of seven vtaA1 negative strains were isolated from animals also carrying vtaAlpositive $H$. parasuis strains (Figure
1- profiles 1, 3, 4 and 11).

Smart et al. (24) started the genotyping study of $H$. parasuis using REP (Restriction Endonuclease Pattern) technique to differentiate samples of the respiratory tract from isolates of the systemic infection. Other genotyping methods such as Multilocus Enzyme Electrophoresis (MEE), Restriction Fragment Length Polymorphism (RFLP), and more recently the fingerprinting and sequencing methods proved to be able to characterize different isolates of $H$. parasuis presenting highly heterogeneous patterns $(2,4,5,9,13,16,18)$. However, most of these methods are long-lasting and expensive; therefore, an alternative technique to overcome these hindrances is ERICPCR.

Rafiee et al. (21) reported the use of ERIC-PCR to characterize isolates of $H$. parasuis. The method proved to be able to typify all isolates according to origin and serovar in a short period of time and at low cost. Oliveira et al. (14) and Olvera et al. (17) also validated ERIC-PCR as a useful technique and confirmed the high heterogeneity of $H$. parasuis isolates. However, they confirmed as well the low reproducibility of the technique which could hinder intralaboratory comparisons. Macedo et al. (8) first used ERIC-PCR technique to characterize Brazilian $H$. parasuis strains and reported, not only that this genotyping method was more discriminatory than serotyping, but also a high genetic diversity among non-typeable strains and the isolates originated from respiratory tract. These results sustain the high genetic variability found in this study.

ERIC-PCR proved to be a valuable method for $H$. parasuis typing, since it discriminated all 50 strains tested, including the non-typeable isolates, among 23 genotypes. It was capable to distinguish isolates of the same and different serovars and, therefore, it is a useful epidemiological tool. Some profiles, as Genotype 4 and 12, comprises samples of the same serovar, animal and farm of origin, but one of them was characterized as non-typeable by serotyping. This could be explained by possible lost of cellular components of capsule naturally or after several reactivations at the laboratory, 
resulting in the change of serovar type, a fact previously described for lung tissue specimens $(10,22)$.

Discriminatory power of ERIC-PCR was higher than serotyping, confirming the statement that serotyping is a poor epidemiological tool for the study of $H$. parasuis, when compared to genotyping methods, such as ERIC-PCR. Although ERIC-PCR proved to be an interesting technique to analyze bacterial samples, its low reproducibility still represents impairment to the future use of the method in intralaboratory comparisons. Therefore, the optimization of genotyping methods to analyze $H$. parasuis, and the study of other pathogenic and virulence mechanisms of the bacterium are necessary to improve its epidemiological study and provide practical information to implement effective prevention and control programs at swine farms in Brazil.

\section{ACKNOWLEDGEMENTS}

This study was sponsored by FAPESP (process: $\underline{07 / 04893-9)}$.

\section{REFERENCES}

1. Biberstein, E.L.; White, D.C. (1969). A proposal for the establishment of two new Haemophilus species. J. Med. Microbiol. 2, 75-78.

2. Blackall, P.J.; Trott, D.J.; Rapp-Gabrielson, V.; Hampson, D.J. (1997) Analysis of Haemophilus parasuis by Multilocus Enzyme Electrophoresis. Vet. Microbiol. 56, 125-134.

3. Boom, R.; Sol, C.J.A.; Salimans, M.M.M.; Jansen, C.L.; Wertheim-Van Dillen, P.M.; Van Der Noorda, J. (1990). Rapid and simple method for purification of nucleic acids. J. Clin. Microbiol. 28, 459-453.

4. De La Puente Redondo, V.A.; Méndez, J.N.; García Del Blanco, N.; Boronát, N.L.; Martín, C.B.G.; Ferri, E.F.R. (2003). Typing of Haemophilus parasuis strains by PCR-RFLP analysis of tha $t b p A$ gene. Vet. Microbiol. 92, 253-262.

5. Del Rio, M.L.; Martin, C.B.; Navas, J.; Gutierrez-Muniz, B.; RodriguezBarbosa, J.L.; Rodriguez Ferri, E.F. (2006). aroA gene PCR-RFLP diversity patterns in Haemophilus parasuis and Actinobacillus species. Res. Vet. Sci. 80, 55-61.

6. Hunter, P.R.; Gaston, M.A. (1988). Numerical index of the discriminatory ability of typing systems: an application of Simpson's index of diversity. J. Clin. Microbiol. 26, 2465-2466.

7. Kielstein, P.; Rapp-Gabrielson, V. J. (1992). Designation of 15 serovars of Haemophilus parasuis on the basis of immunodiffusion using heatsable antigen extracts. J. Clin. Microbiol. 30, 862-865.

8. Macedo, N. R.; Oliveira, S. R.; Lage, A. P.; Santos, J. L.; Araújo, M. R.; Guedes, R. M. C. (2010). ERIC-PCR genotyping of Haemophilus parasuis isolates from Brazilian pigs. Vet. J. doi:10.1016/j.tvj1.2010.05.024

9. Millan, A. S.; Escudero, J. A.; Catalan, A.; Nieto, S.; Farelo, F.; Gilbert, M.; Moreno, M. A.; Dominguez, L.; Gonzalez-Zorn, B. (2007). $\beta$-Lactam resistence in Haemophilus parasuis is mediated by plasmid pB 1000 bearing bla ROB-1. Antimicrob. Agents Chemother. 51, 2260-2264.

10. Morozumi, T.; Nicolet, J. (1986). Morphological variations of Haemophilus parasuis. J. Clin. Microbiol. 23,138-142.

11. Nicolet, J. (1992). Haemophilus parasuis. Diseases of swine. Iowa state university press.

12. Oliveira, S.; Galina, L.; Pijoan, C. (2001). Development of a PCR test to diagnose Haemophilus parasuis infections. J. Vet. Diagn. Invest. 13, 495501.

13. Oliveira, S.; Blackall, P.J.; Pijoan, C. (2003). Characterization of the diversity of Haemophilus parasuis field isolates by use of serotyping and genotyping. American J. Vet. Research. 64, 435-442.

14. Oliveira, S.; Oleson, T.; Titus, M.D.; Simonson, R. (2004). Comparision of Haemophilus parasuis genotyping using amplified fragment lenght polymorphism (AFLP) and ERC-PCR. Am. Ass. Swine Vet. 273-276.

15. Oliveira, S.; Pijoan, C. (2004). Haemophilus parasuis: new trends on diagnosis epidemiology and control. Vet. Microbiol. 99, 1-12.

16. Oliveira, S. (2007). Haemophilus parasuis diagnostics. J. Swine Health Prod. 15, 99-103.

17. Olvera, A.; Calsamiglia, M.; Aragon, V. (2006). Genotypic diversity of Haemophilus parasuis field strains. App. Environ. Microbiol. 72, 39843992.

18. Olvera, A.; Cerdà-Cuéllar, M.; Aragon, V. (2006). Study of the population structure of Haemophilus parasuis by multilocus sequence typing. Microbiology. 152, 3683-3690.

19. Olvera, A.; Pina, S.; Macedo, N.; Oliveira, S.; Aragon, V.; Bensaid, A. (2011). Identification of potentially virulent strains of Haemophilus parasuis using a multiplex PCR for virulence associated autotransporters (vtaA). Vet. J. doi:10.1016/j.tvj1.2010.12.014

20. Pijoan, C.; Trigo, F. (1990). Bacterial adhesion to mucosal surfaces with special reference to Pasteurella multocida isolates from atrophic rhinitis. Can. J. Vet. Res. 54, 16-21.

21. Rafiee, M.; Bara, M.; Stephens, C.P.; Blackall, P.J. (2000). Application of ERIC-PCR for the comparison of isolates of Haemophilus parasuis. Aust. Vet. J. 78(12), 846-849.

22. Rapp-Gabrielson, V.J.; Oliveira, S.R.; Pijoan C. (2006). Haemophilus parasuis. In: Straw, Zimmerman, D’Alleire, Taylor (Eds). Diseases of 
swine. Blackwell Publishing. 681-690.

23. Santos, J.L.; Leite, R.C.; Abreu, V.L.V. (1998). The frequency of Haemophilus parasuis serovars in Brazil. In: IPVS Congress, 278. Birmingham.

24. Smart, N.L.; Hurnik, D.; MacInnes, J.I. (1993). An investigation of enzootic Glasser's disease in a specific pathogen-free grower-finisher facility using restriction endonuclease analysis. Can. Vet. J. 34, 487-490. 25. Versalovic, J.; Koeuth, T.; Lupski, J.R. (1991). Distribution of repetitive DNA sequences in eubacteria and application to fingerprinting of bacterial genomes. Nucleic Acids Res. 19, 6823-6831.

\section{(cc) EY-NC}

All the content of the journal, except where otherwise noted, is licensed under a Creative Commons License 